IJMS 18 (1), 117-134 (2011)

\title{
AN EMPIRICAL INVESTIGATION ON THE RELATIONSHIP BETWEEN RISK OF BANKRUPTCY AND STOCK RETURN
}

\author{
ROHANI MD-RUS \\ UUM College of Business \\ University Utara Malaysia
}

\begin{abstract}
The main objective of the paper is to find out whether bankruptcy risk is a systematic risk. In particular, we investigate the contribution of size, bookto-market, excess market returns and bankruptcy probability in explaining returns. We allocate stocks into portfolios according to the probability of bankruptcy from the hazard model. Results show that bankruptcy risk is not a systematic risk. The results consistently show that excess market returns and size have strong power to explain returns in the UK for the period from 1988 to 1997. Book-to-market and bankruptcy risk only matter in portfolios with higher probability of bankruptcy.
\end{abstract}

Keyword: Bankruptcy risk, bankruptcy probability, hazard model. JEL Classification: G12, G33

\begin{abstract}
Abstrak
Objektif utama kajian ini ialah untuk mengenal pasti sama ada risiko kebankrapan ialah risiko sistematik ataupun tidak. Secara khusunya, kami memeriksa sumbangan saiz, nilai buku kepada nilai pasaran, lebihan pulangan pasaran dan kebarangkalian kebankrapan dalam menerangkan pulangan. Kami membahagikan saham kepada beberapa portfolio berdasarkan kebarangkalian kebankrapan dari Model Hazard. Hasil kajian menunjukkan risiko kebankrapan bukanlah risiko sistematik. Kajian secara konsisten telah menunjukkan bahawa lebihan pulangan pasaran dan saiz mempunyai kuasa yang kuat untuk menerangkan pulangan di UK dalam tempoh 1988 sehingga 1997. Nilai buku kepada nilai pasaran dan risiko kebankrapan hanya penting untuk portfolio yang mempunyai kebarangkalian kebankrapan yang tinggi.
\end{abstract}

Kata kunci: Risiko kebankrapan, kebarangkalian kebankrapan, model hazard. 


\section{Introduction}

A good deal of empirical research has revealed that size and book-tomarket have strong roles in explaining average returns. In particular, Banz (1981); Reinganum (1981), Chan, Chen and Hsieh (1985); Fama and French (1992, 1993, 1995); and He and Ng (1994) found the size effect to be significant in explaining average returns. Rosenberg, Reid and Lanstein (1985); Chan, Hamao and Lakonishok (1991); and Fama and French $(1992,1993,1995)$ found book-to-market to be significant in explaining average returns. Fama and French (1993) showed that portfolios constructed to mimic risk factors related to size and bookto-market add substantially to the variation in stock returns. The three-factor asset pricing model, which includes a market factor and risk factors related to size and book-to-market, seems to capture the cross-section of average returns on US stocks.

Studies in the UK also found a book-to-market effect in explaining average returns (Chan \& Chui, 1996; Strong \& Xu, 1997); but the size effect played no significant role in explaining such returns. Thus, the ability of these factors to explain the variation in average returns has challenged the Capital Asset Pricing Model's (CAPM) proposition that beta is the only variable that explains returns.

There are two reasons why size and book-to-market have predictive ability in explaining returns. The first is that these variables are measuring the riskiness of stocks. Fama and French (1995) explain that if stocks are priced rationally, systematic differences in average returns are due to differences in risk. Thus, with rational pricing, size and book-to-market must proxy for common risk factors in returns. The other explanation is that these variables allow investors to identify stocks that are mispriced, thus creating opportunities for realised returns in excess of what is required to compensate investors for risk (Lakonishok, Shleifer \& Vishny, 1994).

Fama and French (1992) suggest the possibility that risk captured by book-to-market reflects distress risk. High book-to-market firms are associated with distress. A high book-to-market firm, that is a firm with a low stock price relative to book value, signals low earnings on book equity, thereby requiring a higher expected return. Similarly, a low book-to-market ratio is associated with a strong firm. They have a high stock price relative to book value. Such a company should therefore require a lower expected return.

Fama and French (1995) show that firms with a high book-to-market ratio have persistently low earnings. This reflects the fact that firms 
with a high book-to-market are less profitable than firms with a low book-to-market. This is typical of firms that are in distress. They further find that size is related to profitability. Small- sized firms tend to have lower earnings on book equity than do big firms, which suggest that these firms have a high probability of bankruptcy.

The relationship between the probability of bankruptcy, which is a proxy for distress risk, and stock return has been examined by several authors. In particular, the researchers tried to examine whether bankruptcy risk was a systematic risk factor. If bankruptcy risk was systematic, then one would expect a positive association between bankruptcy risk and returns. If bankruptcy risk was partly systematic, then more insolvent firms should have higher returns compared to less insolvent firms. There have been contradictory results regarding this issue. While Lang and Stulz (1992); Denis and Denis (1995); and Shumway (1996) found that bankruptcy risk was a systematic risk, Opler and Titman (1994); Asquith, Gertner and Sharftein (1994); and Dichev (1998) found that bankruptcy risk was unrelated to systematic risk. Shumway (1996) and Dichev (1998) formed portfolios based on the probability of bankruptcy. Similar to Dichev (1998); Zaretzky and Zumwalt (2007) also used Ohlson 's (1980) and Altman's (1968) bankruptcy prediction models to measure financial distress and found that the distress firms have low book-to- market. Other studies that looked into these issues were Vassalou and Xing (2002); Griffin and Lemmon (2002); and Ghargori, Chan and Faff (2009).

Among all the studies cited above, the Shumway (1996), Dichev (1998) and Zaretzky and Zumwalt (2007) studies are interesting because portfolios are formed on the basis of bankruptcy probability derived from a bankruptcy model. Forming portfolios in this manner will reflect the degree of bankruptcy risk that each portfolio carries. However, the results are not consistent. These suggest that the choice of probability measure is very important. Shumway (2001) has shown that the hazard model is superior than the logit model and the MDA model in terms of parameter stability and accuracy of prediction. Moreover, by using firm-year observation, the hazard model can show year-to-year changes in bankruptcy probability where as the MDA and the logit model cannot.

Based on these arguments, this study uses bankruptcy probability obtained from the hazard model as a proxy for default risk. The primary aim of our paper is to explore the relationship between size, book-to-market, bankruptcy probability, beta and return. We also investigate whether bankruptcy probability is a systematic risk factor.

IJMS 18 (1), 117-134 (2011) 119 
The main hypothesis tested is that bankruptcy probability is not a systematic risk factor in returns.

To anticipate the results, we find that bankruptcy risk is not a priced risk factor. The factor mimicking portfolio on distress (DMU) does not have a systematically significant relationship with returns. Excess market returns and size have significant relationships with actual returns.

The paper proceeds as follows. Section 2 describes the data and methodology. Section 3 discusses the results and discussions. Section 4 concludes.

\section{Research Design}

The sample consists of all UK quoted companies listed in Datastream and all bankrupt firms identified in the Stock Exchange yearbook from 1988 to 1997. We use the United Kingdom Bankruptcy Code (1986 Insolvency Act) to define bankruptcy. The Act defines bankrupt firms as those firms that are having financial problems and have entered administration, liquidation and receivership. We use the Stock Exchange Yearbook to identify such firms and exclude all firms that died as a result of takeover or a delisting not associated with bankruptcy. Accounting data on the firms over the period 1988 to 1997 are taken from Datastream International. We use the Dead UK list in Datastream to extract the data. The firm's name from the Stock Exchange Yearbook is matched with the Dead UK list from Datastream. The final sample consists of 1384 non-bankrupt firms and 94 bankrupt firms between the periods 1988 to 1997. Financial firms and property firms are excluded from the sample because the nature of their business is different.

We use firm-year observation and run the hazard model to get the bankruptcy probability for each year. The variables used in the hazard model are size (number of employees and total assets employed), leverage (capital gearing and total debt to total assets), profitability ratio (net income/total assets, return on capital employed), cash flow (cash/total assets, debtor turnover, cash/current liabilities), growth (growth in net income and growth in sales), age, variance of each variable and squares of each variable. The inclusion of variance and squares of each variable is to capture the non-linearities that may exist in the model as suggested by Lennox (1999). We choose ratios based on their previous empirical success. All data are taken from Datastream. 
The dependent variables take a value of 1 if the firm is bankrupt and a value of 0 if it survives. The value of 1 is only used if the firm fails in that particular year; otherwise it has a value of 0 . The hazard model used in this study is in the following form:

$$
\phi\left(t_{i}, x_{i} ; \theta\right)=\frac{1}{1+\exp \left(t_{i}, x_{i}, \theta\right)}
$$

where $\theta$ is the vectors of parameters, $x$ represents a vector of explanatory variables, $t$ represents the time when the firm leaves the sample because of bankruptcy, and $\phi\left(t_{i}, x_{i} ; \theta\right)$ is the hazard function.

Bankruptcy probabilities are saved and used in this study. Specifically, we use the estimated bankruptcy probabilities from the hazard model to construct the distress minus undistress (DMU) portfolio. The small minus big (SMB) market value is the value-weighted return on small firms minus the value-weighted return on large firms while high minus low (HML) book-to-market is the value-weighted return on high book-to-market firms minus the value-weighted return on low book-to-market firms.

We calculate the discrete return and ignore the dividend. This is a standard practice by researchers in this area. We also assume that the UK market is an efficient market, hence ignoring dividends should have little or no impact on the results. The return is defined as $r_{t}=\ln$ $\left(1+R_{t}\right)=\ln \left(P_{t} / P_{t-1}\right)$ where $r_{t}$ is the continuously compounded return, $\left(1+R_{t}\right)$ is the simple gross return on the asset, and $P_{t}$ is the price of an asset at time t. However, by ignoring dividends, this measure will underestimate the total return on healthy dividend-paying stocks relative to non-paying stocks. Excess returns are then constructed by subtracting the risk-free rate (one month Treasury-Bill rate) from the returns.

Following Fama and French (1992) and Dichev (1998), returns are monthly returns beginning six months after the fiscal year-end. For example, a December 31, 1984 fiscal year-end firm will match with the Datastream monthly returns from July 1985 to June 1986. Bankruptcy probability is the probability of bankruptcy predicted from the hazard model.

To construct the factor reflecting distress (DMU), all stocks in the sample are sorted into portfolios formed on the basis of the probability of bankruptcy. The firms are put into one of 10 portfolios arranged in order of increasing bankruptcy probability, each containing the same

IJMS 18 (1), 117-134 (2011) 121 
number of securities. Portfolio 1 contains the firms with the smallest probability of bankruptcy, and portfolio 10 contains those with the highest probability of bankruptcy. Two definitions of DMU are used in this study. First, DMU is the difference, each month, between the average returns on portfolios 8,9 and 10 and the average returns on portfolios 1, 2 and 3. Second, DMU is the difference between the returns on portfolio 10 and the returns on portfolio 1 . The portfolios are formed in June of year t. The equally-weighted monthly returns on the ten portfolios are calculated from July of year $t$ to June of year $\mathrm{t}+1$.

The proxy for the market factor in stock returns is the excess market returns (RM) minus the risk-free rate, which is the rate for one-month treasury bills (RF). The proxy for market returns is the return on the Financial Times All Share Index.

\section{Estimation Technique}

The objective is to investigate whether bankruptcy risk is a systematic risk factor in returns. For this purpose, we estimate a non-linear seemingly unrelated regression (NLSUR) that includes excess market returns, SMB, HML and DMU as explanatory variables. The advantage of using NLSUR is that the sensitivities and the prices of risk can be estimated jointly. This methodology of estimating multifactor models of the risk-return relationship was developed by McElroy, Burmeister \& Wall, (1985). It can be written as

$$
\boldsymbol{R}_{t}=E\left(\boldsymbol{R}_{t}\right)+\boldsymbol{B}_{K} f_{K t}+\varepsilon_{t}
$$

where $\boldsymbol{R}_{t}=$ an $N$ vector of asset returns at time $t$,

$E()=$. the expectations operator,

$f_{K t}=$ the $K$ vector of systematic risk factors common to all assets at time $t$,

$B_{K}=$ the matrix of sensitivities of the assets to the factors and

$\varepsilon_{t}=$ an $\mathrm{N}$ vector of mean zero, serially uncorrelated, idiosyncratic error terms which are orthogonal to the factors.

Expected returns are given by

$$
\mathrm{E}\left(\mathbf{R}_{\mathrm{t}}\right)=\lambda_{0 \mathrm{t}} 1_{\mathrm{N}}+\mathbf{B}_{\mathrm{K}} \lambda_{\mathrm{K}}
$$


where $\lambda_{0 t}=$ the risk-free (or zero beta) rate of return,

$\mathrm{l}_{\mathrm{N}}=$ an $\mathrm{N}$ vector of ones and

$\lambda_{\mathrm{K}}=$ the $K$ vector of prices of risk.

Substituting Eq. (5. 2) into Eq. (5.1) and writing in excess return form gives

$$
\mathbf{R}_{\mathrm{t}}-\lambda_{0 \mathrm{t}} \mathbf{l N}_{\mathrm{N}}=\mathbf{B}_{\mathrm{K}} \lambda_{\mathrm{K}}+\boldsymbol{B}_{K} f_{K t}+\varepsilon_{t}
$$

Rewriting eq. (5.3) as

$$
\boldsymbol{R}-\lambda_{0}=\left\{\boldsymbol{I}_{N} \otimes\left[\left(\boldsymbol{\lambda}^{\prime} \otimes \mathbf{\imath}_{T}\right)+\boldsymbol{F}\right]\right\} \boldsymbol{B}+\varepsilon
$$

where $\boldsymbol{R}_{t}=$ an NT vector of returns,

$\lambda=a \mathrm{~K}$ vector of prices of risk,

$\boldsymbol{F}=\mathrm{a} T \times K$ matrix of observations on the $K$ factors

$\boldsymbol{B}=$ an $N K$ vector of sensitivities,

$I_{N}=$ an $N \times N$ identity matrix and

$\otimes=$ the Kronecker product operator, the non-linear, seemingly unrelated

regression (NLSUR) estimators which provide joint estimates of $\mathbf{B}_{\mathrm{K}}$ and $\lambda_{\mathrm{K}}$ are those that solve the minimisation problem:

$$
\operatorname{Min} \varepsilon^{\prime}\left(\hat{\Sigma}^{-1} \otimes \boldsymbol{I}_{\boldsymbol{T}}\right) \varepsilon
$$

where $\hat{\Sigma}^{-1}$ is the residual variance-covariance matrix estimated from estimating Eq. (5.5) for all $i=1, \ldots, \mathrm{N}$, with $\left(\varepsilon^{\prime} \otimes \imath_{T}\right) \boldsymbol{B}_{i}$ replaced by a constant since $\lambda$ cannot be identified at this stage.

\section{Analysis of Results}

\section{Primary Results}

Table 1 shows the average values of the explanatory variables. Size produces an average value of $-0.6 \%$ with a standard deviation of 0.036 , while book-to-market produces an average value of $0.18 \%$ with a standard deviation of 0.019 . A comparison of these two variables, shows that the size portfolio is riskier and provides a lower return than the HML portfolio. Excess market returns have an average 
value of $0.43 \%$ with a standard deviation of 0.039 while DMU has an average value of $-1.67 \%$ with a standard deviation of 0.024 . The average market risk premium is positive, hence it is consistent with the assumption of risk aversion.

Table 2 presents the Pearson correlation, which shows the relationship between the test variables. DMU has a statistically significant and positive relation with SMB, HML and excess market returns. SMB is negatively correlated with HML and excess market returns, and HML is positively correlated with excess market returns. The correlation between DMU and HML is consistent with the distress hypothesis, that confirms that high-book-to-market has a higher risk of bankruptcy. However, the positive correlation between DMU and SMB is inconsistent with the distress hypothesis, because it indicates that bigger firms have a higher probability of bankruptcy. In conclusion, the results from the Pearson correlation coefficients suggest that HML is related to bankruptcy risk but SMB is not.

Table 1

Descriptive Statistics for the Test Variables (In Percent)

\begin{tabular}{ccc}
\hline Variables & Mean $(\%)$ & Std. Dev. \\
\hline SMB & 0.62 & 0.036 \\
HML & 0.18 & 0.019 \\
DMU & -1.67 & 0.024 \\
RM & 0.43 & 0.039 \\
\hline
\end{tabular}

SMB is the factor mimicking portfolio for size, HML is the factor mimicking portfolio for book-tomarket, RM is the excess market returns and DMU is the factor mimicking portfolio for bankruptcy risk.

Table 2

Pearson Correlation Coefficients for the Test Variables

\begin{tabular}{ccccc}
\hline & SMB & HML & RM & DMU \\
\hline SMB & 1 & & & \\
HML & -.088 & 1 & & \\
RM & $-.360^{* *}$ & .107 & 1 & \\
DMU & $.359^{* *}$ & $.459^{* *}$ & $.236^{*}$ & 1 \\
\hline
\end{tabular}

$\mathrm{SMB}$ is the factor mimicking portfolio for size, HML is the factor mimicking portfolio for book-tomarket, RM is the excess market returns and DMU is the factor mimicking portfolio for bankruptcy risk.

${ }^{*}$ Correlation is significant at $5 \%$ level (2-tailed)

** Correlation is significant at $1 \%$ level (2-tailed

124 IJMS 18 (1), 117-134 (2011) 
Table 3 presents the average excess returns for portfolios formed on the basis of bankruptcy probability. Average excess returns are constructed by subtracting the risk-free rate (one-month Treasury Bill rate) from the actual returns and then averaged across the stocks in the portfolio. The returns are negative because some of the actual returns are less than the risk-free rate, and the portfolios are arranged according to the probability of bankruptcy.

The table shows that there is a wide range of average returns from $-0.3 \%$ to $-3.2 \%$. The results show that portfolio 1 (the lowest probability of bankruptcy) has average excess returns of $-0.3 \%$, while portfolio 10 (the highest probability of bankruptcy) has average excess returns of $-3.2 \%$. The relationship between each portfolio and average returns shows that the returns tend to decrease as the probability of bankruptcy increases.

Table 3

Average Excess Returns on Portfolios Formed on Bankruptcy Probability from the Hazard Model (In Percent)

\begin{tabular}{cc}
\hline Portfolio & Average excess returns* $^{*}$ \\
\hline 1 & -0.3 \\
2 & -0.3 \\
3 & -0.1 \\
4 & -0.4 \\
5 & -0.6 \\
6 & -0.8 \\
7 & -0.9 \\
8 & -0.9 \\
9 & -1.7 \\
10 & -3.2 \\
\hline
\end{tabular}

Portfolios are formed based on bankruptcy probability. Portfolio 1 contains firms with the lowest probability of bankruptcy, while portfolio 10 contains firms with the highest probability of bankruptcy.

* average excess returns are constructed by subtracting the risk-free rate from the returns.

\section{Common Factors in Returns}

The results from estimating the models when DMU is the difference, each month, between the average returns on portfolios 8,9 and 10 and the average returns on portfolios 1,2 and 3 are reported in Tables 4, 5, 6 and 7. From Table 4, it is clear that DMU is not a price risk factor. In other words, bankruptcy risk is not systematic. The estimate 
of DMU is $-0.008 \%$ and is not significant. Excess market returns is also not a risk factor. The estimate of beta is $0.6 \%$ per month with a t-statistic of 0.84 . The results also show that SMB is marginally significant at the $10 \%$ level. HML appears to be the only factor that has a significant price of risk.

Table 4

Estimated Prices of Risk

\begin{tabular}{ccc}
\hline Factors & $\lambda$ & t-statistics \\
\hline RM & 0.005977 & $(0.84)$ \\
SMB & -0.01805 & $(-1.59)^{*}$ \\
HML & -0.00747 & $(-2.00)^{* *}$ \\
DMU & -0.00008 & $(0.86)$ \\
\hline
\end{tabular}

SMB is the small minus big market value, HML is the high minus low book-to-market, DMU is the distress minus undistress bankruptcy probability defined as the difference, each month, between the average returns on portfolios 8,9 and 10 and the average returns on portfolios 1,2 and 3 and $\mathrm{RM}$ is the excess market returns.

* Denotes significant at the $10 \%$ level

${ }^{* *}$ Denotes significant at the $5 \%$ level

Table 5 presents the coefficients of DMU, SMB, HML and excess market returns (RM) in each portfolio. The results show that size and excess market returns are statistically significant and have positive relationships with returns in all portfolios. This indicates that smallersize firms have lower returns and firms with higher risk are expecting higher returns. DMU is statistically significant in portfolios 1, 3, 8, 9 and 10, while HML is statistically significant in portfolios 3, 5, 6, 7, 8 and 9. Overall, HML has positive relationship with returns which indicates that firms with high book-to- market are expecting higher returns. The coefficients on DMU in the portfolios with the highest probability of bankruptcy (portfolios 8,9 , and 10) show positive signs, indicating that, for these three portfolios, the probability of bankruptcy does matter and increases the actual returns. The relationship between DMU and returns is negative in portfolios 1, 2, 3 and 5.

Further analysis is carried out to see the relationship between HML and returns and between DMU and returns. The results are presented in Tables 6 and 7 respectively. Table 6 shows that SMB, HML and $\mathrm{RM}$ are significantly priced. Table 7 shows that SMB and RM show a positive and significant relationship with actual returns. HML shows a significant and positive relationship with actual returns in portfolios $4,5,6,7,8,9$ and 10 . The results show that HML increases the actual returns and it has an impact on expected returns. 
Table 5

NLSUR Estimates on DMU, SMB, HML and RM

\begin{tabular}{|c|c|c|c|c|}
\hline Portfolio & DMU & SMB & HML & $\mathrm{RM}$ \\
\hline 1 & $\begin{array}{l}-0.294 \\
(-3.01)^{* * *}\end{array}$ & $\begin{array}{c}0.766 \\
(12.75)^{* * *}\end{array}$ & $\begin{array}{c}0.156 \\
(1.51)^{*}\end{array}$ & $\begin{array}{r}1.038 \\
(20.7)^{* *}\end{array}$ \\
\hline 2 & $\begin{array}{l}-0.070 \\
(-0.91)\end{array}$ & $\begin{array}{c}0.594 \\
(12.51)^{* * * *}\end{array}$ & $\begin{array}{c}0.011 \\
(0.13)\end{array}$ & $\begin{array}{c}0.938 \\
(23.64)^{* * * * 4}\end{array}$ \\
\hline 3 & $\begin{array}{l}-0.290 \\
(-3.99)^{* *}\end{array}$ & $\begin{array}{c}0.652 \\
(14.51)^{* * * * *}\end{array}$ & $\begin{array}{l}0.274 \\
(3.56)^{* *}\end{array}$ & $\begin{array}{c}1.083 \\
(28.87)^{* * * *}\end{array}$ \\
\hline 4 & $\begin{array}{c}0.016 \\
(0.20)\end{array}$ & $\begin{array}{c}0.525 \\
(10.53)^{* * *}\end{array}$ & $\begin{array}{c}0.144 \\
(1.70)^{*}\end{array}$ & $\begin{array}{c}1.011 \\
(24.31)^{* * *+4}\end{array}$ \\
\hline 5 & $\begin{array}{l}-0.0239 \\
(-0.30)\end{array}$ & $\begin{array}{c}0.594 \\
(12.03)^{*+* * *}\end{array}$ & $\begin{array}{l}0.2189 \\
(2.57)^{* *}\end{array}$ & $\begin{array}{c}0.986 \\
(23.87)^{*+*+*}\end{array}$ \\
\hline 6 & $\begin{array}{l}0.0153 \\
(0.20)\end{array}$ & $\begin{array}{r}0.6389 \\
(13.75)^{* * * *}\end{array}$ & $\begin{array}{l}0.4051 \\
(5.09)^{* *}\end{array}$ & $\begin{array}{c}1.048 \\
(27.04)^{*+* * *}\end{array}$ \\
\hline 7 & $\begin{array}{c}0.118 \\
(1.45)\end{array}$ & $\begin{array}{r}0.642 \\
(12.8)^{* * *+*}\end{array}$ & $\begin{array}{c}0.371 \\
(4.31)^{* * * *}\end{array}$ & $\begin{array}{c}1.040 \\
(24.82)^{* * * *}\end{array}$ \\
\hline 8 & $\begin{array}{l}0.362 \\
(4.19)^{* *+*+1}\end{array}$ & $\begin{array}{c}0.580 \\
(10.77)^{* * *}\end{array}$ & $\begin{array}{c}0.248 \\
(2.67)^{* *}\end{array}$ & $\begin{array}{c}0.999 \\
(22.20)^{* * * *}\end{array}$ \\
\hline 9 & $\begin{array}{l}0.586 \\
(6.11)^{* * * *}\end{array}$ & $\begin{array}{c}0.727 \\
(12.15)^{* * * *}\end{array}$ & $\begin{array}{l}0.301 \\
(2.92)^{* *}\end{array}$ & $\begin{array}{c}1.081 \\
(21.62)^{* * *+*}\end{array}$ \\
\hline 10 & $\begin{array}{c}1.394 \\
(12.19)^{* * * *} \\
\end{array}$ & $\begin{array}{l}0.705 \\
(9.96)^{* * *}\end{array}$ & $\begin{array}{r}-0.109 \\
(-0.90) \\
\end{array}$ & $\begin{array}{c}0.980 \\
(16.59)^{* * *}\end{array}$ \\
\hline
\end{tabular}

Firms are assigned monthly into ten portfolios according to their probability of bankruptcy from the hazard model. Portfolio 1 signifies the lowest probability of bankruptcy while portfolio 10 signifies the highest probability of bankruptcy. SMB is the small minus big market value, HML is the high minus low book-to-market, DMU is the distress minus undistress bankruptcy probability defined as the difference, each month, between the average returns on portfolios 8,9 and 10 and the average returns on portfolios 1, 2 and 3 and RM is the excess market returns. Figures in parentheses are t-statistics.

Denotes significant at $10 \%$ level.

* Denotes significant at $5 \%$ level.

${ }^{* * *}$ Denotes significant at $1 \%$ level.

Table 6

Estimated Prices of Risk Represented by SMB, HML And RM

\begin{tabular}{ccc}
\hline Factors & $\lambda$ & t-statistics \\
SMB & -0.04421 & $(-3.33)^{* *}$ \\
HML & -0.01003 & $(-2.20)^{* *}$ \\
RM & 0.0228 & $(2.83)^{* *}$ \\
\hline
\end{tabular}

SMB is the small minus big market value, HML is the high minus low book-to-market, DMU is the distressed minus undistressed bankruptcy probability defined as the difference, each month, between the average returns on portfolios 8,9 and 10 and the average returns on the portfolios 1, 2 and 3 and RM is the excess market returns.

${ }^{* *}$ Denotes significant at the $5 \%$ level 
Table 7

\section{NLSUR Estimates on SMB, HML and RM}

\begin{tabular}{|c|c|c|c|}
\hline Portfolio & SMB & HML & $\mathrm{RM}$ \\
\hline 1 & $\begin{array}{c}0.623 \\
(14.51)^{* * * *}\end{array}$ & $\begin{array}{l}-0.040 \\
(-0.46)\end{array}$ & $\begin{array}{c}0.981 \\
(21.20)^{* * *}\end{array}$ \\
\hline 2 & $\begin{array}{c}0.568 \\
(16.56)^{* * * *}\end{array}$ & $\begin{array}{c}-0.026 \\
(-0.40)\end{array}$ & $\begin{array}{c}0.923 \\
(26.21)^{* * *}\end{array}$ \\
\hline 3 & $\begin{array}{c}0.553 \\
(15.56)^{* * *}\end{array}$ & $\begin{array}{c}0.111 \\
(1.67)\end{array}$ & $\begin{array}{c}1.018 \\
(28.58)^{* * *}\end{array}$ \\
\hline 4 & $\begin{array}{c}0.566 \\
(15.79)^{* * * *}\end{array}$ & $\begin{array}{c}0.176 \\
(2.54)^{* *}\end{array}$ & $\begin{array}{c}1.009 \\
(27.09)^{* * *}\end{array}$ \\
\hline 5 & $\begin{array}{c}0.595 \\
(17.41)^{* * * *}\end{array}$ & $\begin{array}{c}0.2098 \\
(3.07)^{* *}\end{array}$ & $\begin{array}{c}0.978 \\
(26.46)^{* * *}\end{array}$ \\
\hline 6 & $\begin{array}{c}0.649 \\
(18.71)^{* * *}\end{array}$ & $\begin{array}{c}0.400 \\
(6.13)^{* * *}\end{array}$ & $\begin{array}{c}1.054 \\
(30.19)^{* * *}\end{array}$ \\
\hline 7 & $\begin{array}{c}0.685 \\
(18.91)^{* * * *}\end{array}$ & $\begin{array}{c}0.431 \\
(6.17)^{* * *}\end{array}$ & $\begin{array}{c}1.067 \\
(28.43)^{* * *}\end{array}$ \\
\hline 8 & $\begin{array}{c}0.709 \\
(17.39)^{* * * *}\end{array}$ & $\begin{array}{c}0.457 \\
(5.61)^{* *}\end{array}$ & $\begin{array}{c}1.087 \\
(24.73)^{* * *}\end{array}$ \\
\hline 9 & $\begin{array}{c}0.912 \\
(18.17)^{* * *}\end{array}$ & $\begin{array}{c}0.620 \\
(6.36)^{* * *}\end{array}$ & $\begin{array}{c}1.219 \\
(23.30)^{* * *}\end{array}$ \\
\hline 10 & $\begin{array}{c}1.196 \\
(14.53)^{* * *}\end{array}$ & $\begin{array}{c}0.675 \\
(4.56)^{* *}\end{array}$ & $\begin{array}{c}1.290 \\
(16.47)^{* * *}\end{array}$ \\
\hline
\end{tabular}

Firms are assigned monthly into ten portfolios according to their probability of bankruptcy in the hazard model. Portfolio 1 signifies the lowest probability of bankruptcy while portfolio 10 signifies the highest probability of bankruptcy. SMB is the small minus big market value, HML is the high minus low book-to-market, DMU is the distressed minus undistressed bankruptcy probability defined as the difference, each month, between the average returns on portfolios 8, 9 and 10 and the average returns on the portfolios 1, 2 and 3 and RM is the excess market returns. Figures in parentheses are t-statistics.

${ }^{* *}$ Denotes significant at $5 \%$ level.

Denotes significant at $1 \%$ level.

Table 8

Estimated Prices of Risk With SMB, DMU and RM

\begin{tabular}{ccc}
\hline Factors & $\lambda$ & t-statistics \\
\hline SMB & -0.02077 & $(-1.89)^{*}$ \\
DMU & -0.00012 & $(-1.01)$ \\
RM & 0.007 & $(1.13)$ \\
\hline
\end{tabular}

SMB is the small minus big market value, HML is the high minus low book-to-market, DMU is the distressed minus undistressed bankruptcy probability defined as the difference, each month, between the average returns on portfolios 8,9 and 10 and the average returns on portfolios 1,2 and

3 and $\mathrm{RM}$ is the excess market returns.

* Denotes significant at the $10 \%$ level

128 IJMS 18 (1), 117-134 (2011) 
Regarding the relationship between DMU and actual returns, Table 8 shows that DMU is not a price risk factor. The estimate of DMU is $-0.012 \%$ and is not significant. Excess market returns are also not significant, while size is significant at $10 \%$ level. Table 9 shows that DMU is positive and significant in portfolios 6, 7, 8, 9 and 10, which suggests that for these portfolios, DMU increases the actual returns. SMB and RM are statistically significant in all portfolios.

Table 9

NLSUR Estimates on SMB, DMU and RM

\begin{tabular}{|c|c|c|c|}
\hline Portfolio & SMB & $\mathrm{DMU}$ & $\mathrm{RM}$ \\
\hline \multirow[t]{2}{*}{1} & 0.731 & -0.215 & 1.026 \\
\hline & $(13.04)^{* * * *}$ & $(-2.66)^{* *}$ & $(20.80)^{* * * *}$ \\
\hline \multirow[t]{2}{*}{2} & 0.5898 & -0.066 & 0.937 \\
\hline & $(13.24)^{* * * *}$ & $(-1.05)$ & $(24.40)^{* * * *}$ \\
\hline \multirow[t]{2}{*}{3} & 0.597 & -0.142 & 1.058 \\
\hline & $(13.60)^{* * *}$ & $(-2.25)^{* *}$ & $(27.41)^{*+*+*}$ \\
\hline \multirow[t]{2}{*}{4} & 0.498 & 0.096 & 0.998 \\
\hline & $(10.68)^{* * *}$ & (1.42) & $(24.36)^{* * *}$ \\
\hline \multirow[t]{2}{*}{5} & 0.551 & 0.093 & 0.966 \\
\hline & $(11.72)^{* * *}$ & $(1.40)$ & $(23.27)^{* *+*}$ \\
\hline \multirow[t]{2}{*}{6} & 0.562 & 0.232 & 1.14 \\
\hline & $(11.77)^{* * * *}$ & $(3.40)^{* *}$ & $(24.12)^{* * * *}$ \\
\hline \multirow[t]{2}{*}{7} & 0.569 & 0.317 & 1.007 \\
\hline & $(11.44)^{* * * *}$ & $(4.48)^{* *}$ & $(22.93)^{* * * *}$ \\
\hline \multirow[t]{2}{*}{8} & 0.527 & 0.500 & 0.977 \\
\hline & $(10.22)^{* * * *}$ & $(6.82)^{* * * *}$ & $(21.49)^{* * * *}$ \\
\hline \multirow[t]{2}{*}{9} & 0.662 & 0.748 & 1.053 \\
\hline & $(11.51)^{* * *}$ & $(9.19)^{* * * *}$ & $(20.74)^{* * *}$ \\
\hline \multirow[t]{2}{*}{10} & 0.726 & 1.325 & 0.992 \\
\hline & $(11.07)^{* * *}$ & $(14.11)^{* * *}$ & $(17.15)^{* * *}$ \\
\hline
\end{tabular}

Firms are assigned monthly into ten portfolios according to their probability of bankruptcy in the hazard model. Portfolio 1 signifies the lowest probability of bankruptcy while portfolio 10 signifies the highest probability of bankruptcy. SMB is the small minus big market value, HML is the high minus low book-to-market, DMU is the distressed minus undistressed bankruptcy probability defined as the difference, each month, between the average returns on portfolios 8,9 and 10 and the average returns on portfolios 1, 2 and 3 and RM is the excess market returns. Figures in parentheses are t-statistics.

${ }^{* *}$ Denotes significant at $5 \%$ level.

**** Denotes significant at $1 \%$ level. 
In order to assess the sensitivity of the results to the definition of the distress factor, we also estimate regression using an alternative definition of the distress factor, DMU, which is defined as the difference between the extreme portfolios. The results are presented in Table 10. As can be seen from the table, the usage of an alternative definition of distress does not change the conclusion regarding the significance of the distress factor. Table 10 shows that DMU is not a risk factor. The estimate of DMU is $-0.004 \%$ and is not statistically significant. Size is significant at $5 \%$ level, but excess market returns are not.

Table 10

Estimated Prices of Risk With SMB, DMU and RM Using the Extreme Portfolio

\begin{tabular}{ccc}
\hline Factors & $\lambda$ & t-statistics \\
\hline SMB & -0.02406 & $(-2.38)^{* *}$ \\
DMU & -0.00004 & $(-0.70)$ \\
RM & 0.00929 & $(1.50)$ \\
\hline
\end{tabular}

SMB is the small minus big market value, HML is the high minus low book-to-market, DMU is the distressed minus undistressed bankruptcy probability defined as the difference, each month, between the returns on portfolio 10 and the returns on portfolio 1, and RM is the excess market returns. Figures in parentheses are t-statistics.

${ }^{* *}$ Denotes significant at the $5 \%$ level

Table 11 shows that DMU is positive and statistically significant in portfolios 6, 7, 8, 9 and 10. Again, this suggests that DMU only matters in portfolios with a higher probability of bankruptcy. Size and excess market returns are statistically significant in all portfolios.

Table 11

NLSUR Estimates on SMB, DMU and RM Using the Extreme Portfolio

\begin{tabular}{|c|c|c|c|}
\hline Portfolio & SMB & DMU & $\mathrm{RM}$ \\
\hline 1 & $\begin{array}{c}0.770 \\
(15.52)^{* * * * *}\end{array}$ & $\begin{array}{l}-0.206 \\
(-4.82)^{* * *}\end{array}$ & $\begin{array}{c}1.044 \\
(23.4)^{* * * *}\end{array}$ \\
\hline 2 & $\begin{array}{c}0.569 \\
(13.89)^{* * * * *}\end{array}$ & $\begin{array}{c}-0.02 \\
(-0.57)\end{array}$ & $\begin{array}{c}0.928 \\
(24.75)^{* * * *}\end{array}$ \\
\hline 3 & $\begin{array}{c}0.557 \\
(13.25)^{* * * *}\end{array}$ & $\begin{array}{l}-0.0393 \\
(-1.09)\end{array}$ & $\begin{array}{c}1.037 \\
(27.18)^{* * * *}\end{array}$ \\
\hline
\end{tabular}




\begin{tabular}{|c|c|c|c|}
\hline Portfolio & SMB & DMU & $\mathrm{RM}$ \\
\hline 4 & $\begin{array}{r}0.5257 \\
(12.01)^{* * *}\end{array}$ & $\begin{array}{c}0.028 \\
(0.74)\end{array}$ & $\begin{array}{c}1.011 \\
(25.46)^{*+*+}\end{array}$ \\
\hline 5 & $\begin{array}{r}0.585 \\
(13.3)^{* * *}\end{array}$ & $\begin{array}{c}0.013 \\
(0.36)\end{array}$ & $\begin{array}{c}0.984 \\
(24.37)^{* * * *}\end{array}$ \\
\hline 6 & $\begin{array}{c}0.608 \\
(13.35)^{* * * *}\end{array}$ & $\begin{array}{l}0.087 \\
(2.23)^{* *}\end{array}$ & $\begin{array}{c}1.041 \\
(24.96)^{* * * *}\end{array}$ \\
\hline 7 & $\begin{array}{c}0.642 \\
(13.15)^{* * * *}\end{array}$ & $\begin{array}{c}0.105 \\
(2.51)^{* *}\end{array}$ & $\begin{array}{c}1.048 \\
(23.36)^{* * * *}\end{array}$ \\
\hline 8 & $\begin{array}{c}0.669 \\
(12.00)^{* * * *}\end{array}$ & $\begin{array}{l}0.125 \\
(2.62)^{* *}\end{array}$ & $\begin{array}{c}1.057 \\
(20.59)^{* * *+}\end{array}$ \\
\hline 9 & $\begin{array}{c}0.851 \\
(12.57)^{* * * *}\end{array}$ & $\begin{array}{c}0.218 \\
(3.76)^{* *}\end{array}$ & $\begin{array}{c}1.162 \\
(18.82)^{*+*+}\end{array}$ \\
\hline 10 & $\begin{array}{c}0.770 \\
(15.51)^{* * * *}\end{array}$ & $\begin{array}{c}0.794 \\
(18.54)^{* * * *}\end{array}$ & $\begin{array}{c}1.044 \\
(23.39)^{*+*+*}\end{array}$ \\
\hline
\end{tabular}

Firms are assigned monthly into ten portfolios according to their probability of bankruptcy in the hazard model. Portfolio 1 signifies the lowest probability of bankruptcy while portfolio 10 signifies the highest probability of bankruptcy. SMB is the small minus big market value, HML is the high minus low book-to-market, DMU is the distressed minus undistressed bankruptcy probability, defined as the difference, each month, between the returns on portfolio 10 and the returns on portfolio 1. RM is the excess market returns. Figures in parentheses are t-statistics.

${ }^{* *}$ Denotes significant at $5 \%$ level.

*** Denotes significant at $1 \%$ level.

To summarise, regardless of the definition of DMU, SMB and RM, these variables are significant in explaining returns in the UK from 1988 to 1997. The use of an alternative definition of distress does not have any impact on the conclusions regarding the significance of the distress factor. It clearly shows that DMU is not significantly priced and therefore it is not a systematic risk. The result that bankruptcy risk is not systematic is similar to that found by Opler and Titman (1994), Asquith, Gertner and Sharftein (1994) and Dichev (1998). Regarding the relationship between DMU and returns, the results show that DMU increases the actual returns in portfolios 6, 7, 8, 9, and 10. On the other hand, HML is a significant risk factor. Like DMU, HML also increases actual returns in portfolios 6, 7, 8, 9, and 10 .

\section{Conclusions}

This study has analysed the contribution of size, book-to-market, excess market returns and the probability of bankruptcy in explaining returns. If stocks are priced rationally, then the differences in returns must be due to the risk factor. This study also attempts to answer the question whether bankruptcy risk is systematic or not. 
To examine this issue, stocks are allocated into portfolios according to the probability of bankruptcy in the hazard model. Distress minus undistress (DMU) portfolios are constructed as (1) the difference between the average returns on portfolios 8,9 and 10 and the average returns on portfolios 1, 2 and 3, and (2) the difference between the returns on portfolio 10 and the returns on portfolio 1 . The different definition of DMU is essential in order to assess the sensitivity of the results.

The empirical findings indicate that, at least during the 1988 to 1997 time period, bankruptcy risk is not a priced risk factor regardless of the definition of DMU. Also, regardless of the definition of DMU, size is significantly priced. Book-to-market, and excess market returns are significantly priced when DMU is defined as the difference between the average returns on portfolios 8,9 and 10 and the average returns on portfolios 1, 2 and 3. Regarding factors that explain returns, the results consistently show that excess market returns and size have strong power to explain returns in the UK. Book-to-market and DMU only matter in portfolios with higher probability of bankruptcy, that is in portfolios 6, 7, 8, 9 and 10 .

Finally, the above study shows that bankruptcy risk and market price behaviour are related. It also shows that bankruptcy risk is not priced. These conclusions are based on the assumption of constant risk. It also uses the financial year-end as the event date. Therefore, future research should use database that includes the bankruptcy announcement date and should consider the use of other methods such as conditional CAPM that allows risk to vary.

\section{References}

Altman, E I. (1968). Financial ratios, discriminant analysis and the prediction of corporate bankruptcy. Journal of Finance, 23, 589609.

Asquith, P., Gertner R., \& Sharfstein D. (1994). Anatomy of financial distress: An examination of junk-bond issuer. Quarterly Journal of Economics, 109, 625-58.

Banz, R. W. (1981). The relationship between return and market value of common stocks. Journal of Financial Economics, 9, 3-18.

Chan , A., \& Chui, A. P. L. (1996). An empirical re-examination of the cross-section of expected returns: UK evidence. Journal of Business, Finance and Accounting, 23(9) \& (10), 1435-1452. 
Chan, K. C., Chen, N. F., \& Hsieh, D. (1985). An explanatory investigation of the firm size effect. Journal of Financial Economics, 14, 451-471.

Chan, L., Hamao, Y., \& Lakonishok, J. (1991). Fundamentals and stock returns in Japan. Journal of Finance, 46, 1739-1764.

Denis, D. J., \& Denis, D. (1995). Causes of financial distress following leveraged recapitalizations. Journal of Financial Economics, 2, 411-418.

Dichev, I. (1998). Is the risk of bankruptcy a systematic risk? Journal of Finance, 53, 1131-1148.

Fama, E. F., \& French, K. R. (1992). The cross-section of expected returns. Journal of Finance, 47, 427-465.

Fama, E. F., \& French, K. R. (1993). Common risk factors in the returns on stocks and bonds. Journal of Financial Economics, 33, 3-56.

Fama, E. F., \& French, K. R. (1995). Size and book-to-market factors in earning and returns. Journal of Finance, 50, 131-55.

Gharghori, P., Chan H., \& Faff, R. (2009). Default risk and equity returns: Australian evidence. Pacific Basin Finance Journal, 17, 580-593.

Griffin, J., \& Lemmon, M. (2002). Book-to-market equity, distress risk, and stock return. Journal of Finance, LVII (5), 2317-2336.

He, J., \& Ng, L. K. (1994). Economic forces, fundamental variables and equity returns. Journal of Business, 67, 599-639.

Lakonishok, J., Shleifer, A., \& Vishny, R. (1994). Contrarian investment, extrapolation, and risk. Journal of Finance, XLIX (5), 1541-1578.

Lang, L., \& Stulz, R. (1992). Contagion and competitive intra-industry effects of bankruptcy announcements. Journal of Financial Economics, 32, 45-60.

Lennox, C. (1999). Identifying failing companies: A re-evaluation of the logit, probit and MDA approaches. Journal of Economics and Business, 51(4), 347-364.

McElroy, M. B., Burmeister, E., \& Wall, K. D. (1985). Two estimators for the APT model when factors are measured. Economic Letters, 19, 271-275.

Ohlson, J. A. (1980). Financial ratios and the probabilistic prediction of bankruptcy. Journal of Accounting Research, 18, 109-131.

Opler, T., \& Titman, S. (1994). Financial distress and corporate performance. Journal of Finance, 49, 1015-1040.

Pontiff, J., \& Schall, L. D. (1998). Book-to-market as predictors of market returns. Journal of Financial Economics, 49, 141-160.

Reinganum, M. R. (1981). Misspecification of capital asset pricingempirical anomalies based on earnings' yields and market values. Journal of Financial Economics, 9, 19-46. 
Rosenberg, B., Reid, K., \& Lanstein, R. (1984). Persuasive evidence of market inefficiency. Journal of Portfolio Management, 11, 9-17.

Shumway, T. (1996). Size, overreaction and book-to-market effects as default premia. Working paper, University of Michigan.

Shumway, T. (2001). Forecasting bankruptcy more accurately: A simple hazard model. Journal of Business, 74 (1), 101-124.

Strong, N., \& Xu, X.G. (1997). Explaining the cross-section of UK expected stock returns. British Accounting Review, 29, 1-23.

Vassalou, M., \& Xing, Y. (2004). Default risk in equity returns. Journal of Finance, 59, 831-868.

Zaretzky, K., \& Zumwalt, J. K. (2007). Relation between distress risk, book-to-market ratio and return premium. Managerial Finance, 33(10), 788-797. 